\title{
PENGGUNAAN MODEL PROBLEM BASED LEARNING UNTUK MENINGKATKAN AKTIVITAS BELAJAR SISWA PADA SUB TEMA KEBERAGAMAN BUDAYA BANGSAKU
}

\author{
Rudi Triadi Ramadhan ${ }^{1}$, Abdul Mumin Saud ${ }^{2}$ \\ ${ }^{1}$ SDN Nyomplang 1 \\ ${ }^{2}$ Universitas Pasundan \\ 1rudi.triadi@gmail.com \\ 2abdulmuminsaud@unpas.ac.id
}

\begin{abstract}
This research is based on teacher activity in teaching which still use conventional model where teacher centered learning (teacher center) so that it causes low learning activity and student learning result. The purpose of this study to improve student learning activities, caring attitude, and courteous students and student learning outcomes both on the aspects of knowledge and skills in thematic learning theme Beautifulness Togetherness subtema Cultural Diversity of My Country. This study uses a classroom research method consisting of three cycles. The subject of this research is the fourth grade students of SDN Nyomplong 1, as many as 20 people consist of 12 male students and 8 female students. Based on the results of research on the first cycle on the activity aspect reached $66.2 \%$ with good category (B), in the second cycle reached $75 \%$ with good category $(B)$, and in the third cycle reached $93.5 \%$ with very good category $(A)$. Learning outcomes on the affective aspect of the attitude of care and polite tend to be in the category of enough (C), in cycle II the tendency of student attitudes increased in either category (B), in cycle III the tendency of student attitudes increased in the category of excellent (A) Students. Learning outcomes on the knowledge aspects of the cycle I number of students who complete the KKM as many as 9 people or by $45 \%$ and students who have not completed to reach KKM as many as 11 students or by $55 \%$. In cycle II the number of students who complete the KKM as many as 12 people or $60 \%$ and unfinished students to reach KKM as many as 8 students or by $40 \%$. In cycle III the number of students who complete the KKM as many as 17 people or by $85 \%$ and students who have not completed reach KKM as many as 3 students or by $15 \%$. In skill aspect in cycle I skill of student in looking for information tends to be in enough category (C). In cycle II the students' skill tends to be in good category (B), In cycle III students skill tend to be in very good category (A). The conclusion in this research is the use of Problem Based Learning model can improve student learning activity on thematic learning theme of beautiful togetherness of my nation's cultural diversity.
\end{abstract}

Keywords: Problem Based Learning, Student Learning Activities, Learning Outcomes. 


\section{ABSTRAK}

Penelitian ini dilatar belakangi oleh aktivitas guru dalam mengajar yang masih menggunakan model konvensional dimana pembelajaran berpusat pada guru (teacher center) sehingga menyebabkan rendahnya aktivitas belajar dan hasil belajar siswa. Tujuan penelitian ini untuk meningkatkan aktivitas belajar siswa, sikap peduli, dan santun siswa serta hasil belajar siswa baik pada aspek pengetahuan maupun keterampilan pada pembelajaran tematik tema Indahnya Kebersamaan subtema Keberagaman Budaya Bangsaku. Penelitian ini menggunakan metode penelitian kelas yang terdiri dari tiga siklus. Subjek penelitian ini adalah siswa kelas IV SDN Nyomplong 1, sebanyak 20 orang yang terdiri dari 12 siswa laki-laki dan 8 siswi perempuan. Berdasarkan hasil penelitian pada siklus I pada aspek aktivitas mencapai $66,2 \%$ dengan kategori baik (B), di siklus II mencapai $75 \%$ dengan kategori baik (B), dan pada siklus III mencapai 93,5\% dengan kategori sangat baik (A). Hasil belajar pada aspek afektif yaitu sikap peduli dan santun cenderung berada pada kategori cukup (C), pada siklus II kecenderungan sikap siswa meningkat pada kategori baik (B), pada siklus III kecenderungan sikap siswa meningkat pada kategori sangat baik (A) dari jumlah keseluruhan siswa. Hasil belajar pada aspek kognitif pada siklus I jumlah siswa yang tuntas mencapai KKM sebanyak 9 orang atau sebesar $45 \%$ dan siswa yang belum tuntas mencapai KKM sebanyak 11 orang siswa atau sebesar $55 \%$. Pada siklus II jumlah siswa yang tuntas mencapai KKM sebanyak 12 orang atau sebesar $60 \%$ dan siswa yang belum tuntas mencapai KKM sebanyak 8 orang siswa atau sebesar $40 \%$. Pada siklus III jumlah siswa yang tuntas mencapai KKM sebanyak 17 orang atau sebesar $85 \%$ dan siswa yang belum tuntas mencapai KKM sebanyak 3 orang siswa atau sebesar $15 \%$. Pada aspek keterampilan pada siklus I keterampilan siswa dalam mencari informasi cenderung berada pada kategori cukup (C). Pada siklus II keterampilan siswa cenderung berada pada kategori baik (B), Pada siklus III keterampilan siswa cenderung berada pada kategori sangat baik (A). Kesimpulan dalam penelitian ini adalah penggunaan model Problem Based Learning dapat meningkatkan aktivitas belajar siswa pada pembelajaran tematik tema indahnya kebersamaan keberagaman budaya bangsaku.

Kata Kunci : Problem Based Learning, Aktivitas Belajar Siswa, Hasil Belajar Siswa.

\section{A. PENDAHULUAN}

Memperoleh pendidikan merupakan hak setiap manusia karena pendidikan memiliki peranan penting bagi keberlangsungan hidup dan masa depan seseorang. Dengan adanya pendidikan dapat membantu dalam menciptakan suatu gambaran yang jelas mengenai hal di sekitar kita. Pendidikan menjadi salah satu faktor utama dalam kemajuan suatu bangsa. Suatu bangsa yang akan memiliki sumber daya manusia yang berkualitas dan tidak mudah 
Pendas : Jurnal Ilmiah Pendidikan Dasar, ISSN Cetak : 2477-2143 ISSN Online : 2548-6950

diperbudak oleh pihak lain. Pendidikan merupakan kebutuhan utama bagi bangsa yang ingin maju dan berkembang.

Pengertian pendidikan menurut undang-undang sistem pendidikan nasional Pasal 1 No.20 tahun 2013, yakni: "Sebagai usaha sadar dan terencana untuk mewujudkan usasana belajar dan proses pembelajaran sedemikian rupa supaya peserta didik dapat mengembangkan potensi dirinya secara aktif supaya memiliki pengendalian diri, kecerdasan, keterampilan dalam bermasyarakat, kekuatan spiritual keagaman, kepribadian serta akhlak mulia, serta keterampilan dirinya, masyarakat bangsa dan negara".

Sangatlah penting dalam upaya mengembangkan potensi, minat, bakat dan potensi yang dimiliki manusia. Oleh sebab itu peran pendidikan sangat penting dalam suatu bangsa, yang tertera dalam undang-undang sistem pendidikan nasional No.20 tahun 2003 Bab II Pasal 3, bahwa: "Pendidikan nasional berfungsi mengembangkan kemampuan dan membentuk watak serta peradaban bangsa yang bermartabat dalam rangka mencerdaskan kehidupan bangsa. Pendidikan Nasional bertujuan untuk berkembangnya potensi peserta didik menjadi manusia yang beriman dan bertakwa kepada Tuhan Yang Maha Esa, berakhlak mulia, sehat, berilmu, cakap, kreatif, mandiri dan menjadi warga Negara yang demokratis serta bertanggung jawab".

Kegiatan

pendidikan diselenggarakan di berbagai satuan pendidikan.

Satuan-satuan pendidikan tersebut terdapat tiga jalur pendidikan yaitu pendidikan informal, formal, dan non formal. Dalam proses pendidikan formal di Indonesia, tingkat satuan pendidikan yang dianggap sebagai tahap awal pendidikan, pendidikan adalah sekolah dasar. Penyelenggaraan pendidikan dasar dengan tujuan membekali dasar pengetahuan, sikap, serta keterampilan kepada peserta didik, pendidikan dasar ini akan dikembangkan untuk meningkatkan kualitas peserta didik. Untuk memiliki kecakapan dasar peserta didik peran guru sangatlah penting, dalam UU guru dan dosen Pasal 1, yakni: "Guru adalah pendidik professional dengan tugas utama mendidik, mengajar, membimbing, mengarahkan, melatih, menilai, dan 
Pendas : Jurnal Ilmiah Pendidikan Dasar, ISSN Cetak : 2477-2143 ISSN Online : 2548-6950

mengevaluasi peserta didik pada pendidikan anak usia dini jalur pendidikan formal, pendidikan dasar, dan pendidikan menengah". (Undang-undang No.14 Tahun 2005). Dalam pelaksanaan pendidikan dasar, mutu pendidikan sangat bergantung pada keadaan gurunya. Guru adalah faktor penentu keberhasilan belajar di samping alat, fasilitas, sarana dan kemampuan siswa itu sendiri, termasuk partisipasi orangtua dan masyarakat. Menyangkut faktor guru, banyak keterampilan yang harus dimilikinya, guru harus menguasai dengan baik agar proses pendidikan menjadi penuh makna dan selalu relevan dengan tujuan dan bahan ajarannya.

Menurut Cooper 1984 (dalam Djam'an Satori, 2011, hlm. 2.24) terdapat empat komponen kompetensi professional guru, yaitu : (a) mempunyai pengetahuan tentang belajar dan tingkah laku manusia; (b) mempunyai pengetahuan dan menguasai bidang studi yang dibinanya; (c) mempunyai sikap yang tepat tentang diri sendiri, sekolah, teman sejawat dan bidang studi yang dibinanya; dan (d) mempunyai keterampilan dalam teknik mengajar. Keadaan guru dalam pengembangan tugas profesional ke pendidikan khususnya dalam perencanaan, pelaksanaan dan evaluasi pembelajaran perlu adanya kurikulum.

Peran kurikulum sangat penting dalam mencapai tujuan pembelajaran, dalam undang-undang sistem pendidikan nasional No.20 Tahun 2003 Bab 1 ketentuan umum pasal 1 ayat 19 menyatakan bahwa: "Kurikulum adalah seperangkat rencana dan pengaturan mengenai tujuan, isi, dan bahan pelajaran serta cara yang digunakan sebagai pedoman penyelenggaraan kegiatan pembelajaran untuk mencapai tujuan pembelajaran tertentu". Indonesia mengalami beberapa kali inovasi dalam penerapan kurikulum, pada tanggal 11 Desember 2014 menteri pendidikan dan kebudayaan mengeluarkan peraturan nomor 160 tahun 2014 yaitu pemberlakuan kurikulum 2006 dan kurikulum 2013.

Kurikulum 2013 dapat diberlakukan oleh setiap sekolah sesuai dengan kesiapan sekolah yang akan menggunakannya, kini seluruh sekolah di Indonesia diwajibkan menggunakan kurikulum 2013. Dalam tugasnya sebagai guru, guru berkewajiban melakukan tugas- 
Pendas : Jurnal Ilmiah Pendidikan Dasar, ISSN Cetak : 2477-2143 ISSN Online : 2548-6950

Volume II Nomor 1, Juni 2017

tugas sebagaimana dalam Undangundang RI No.14 Tahun 2005 Pasal 20 poin a yang menyatakan bahwa: "Dalam melaksanakan tugas keprofesionalan, guru berkewajiban merencanakan pembelajaran, melaksanakan proses pembelajaran yang bermutu, serta menilai dan mengevaluasi hasil pembelajaran".

Pada SDN Nyomplong 1 menggunakan kurikulum 2013, peneliti mengobservasi siswa kelas IV masih terdapat banyak masalahmasalah yang terjadi, berdasarkan fakta yang ditemukan peneliti menemukan rendahnya aktivitas belajar siswa di kelas IV SD Nyomplong 1 yang berjumlah 20 siswa yang terdiri dari 12 siswa lakilaki dan 8 siswi perempuan yang kurang dari $50 \%$ siswa mendapatkan nilai yang belum mencapai kriteria ketuntasan minimal yang telah ditentukan. $40 \%$ siswa telah mampu mencapai KKM sedangkan 60\% masih berada dibawah KKM. Dan dalam aktivitas siswa masih cukup rendah dimana hanya 6 peserta didik yang terlihat aktif sementara 14 peserta didik belum terlihat aktif.

Masalah-masalah yang ditemukan peneliti saat observasi diantaranya yaitu, kegiatan pembelajaran yang terlihat masih monoton, dimana guru hanya menggunakan model ceramah saja tanpa menggunakan pendekatanpendekatan model pembelajaran lain yang variatif, kurangnya sarana penunjang dalam proses pembelajaran, ada beberapa anak yang masih sulit untuk diatur dan diarahkan, ada yang asik mengerjakan dan ada pula yang sibuk sendiri dengan permainannya hal tersebut dikarenakan guru kurang mampu menguasai kelas dengan baik, guru menyampaikan materi hanya satu arah (tanpa melibatkan siswa), guru tidak memperhatikan kondisi siswa sehingga siswa kurang memahami dalam pembelajaran sehingga berpengaruh terhadap hasil pembelajaran yang rendah.

Pada masalah-masalah yang ditemukan peneliti, model pembelajaran akan menjadi hal yang sangat berpengaruh dalam keberhasilan suatu proses pembelajaran. Menurut Arends 2008 (dalam Hosnan, 2014, hlm. 295) Model Problem Based Learning adalah model pembelajaran dengan pendekatan pembelajaran siswa pada masalah autentik sehingga siswa dapat menyusun 
Pendas : Jurnal Ilmiah Pendidikan Dasar, ISSN Cetak : 2477-2143 ISSN Online : 2548-6950

pengetahuannya

sendiri,

menemukembangkan keterampilan yang lebih tinggi dan inquiry, memandirikan siswa dan meningkatkan kepercayaan diri sendiri. Sedangkan menurut Tan 2004 (dalam Rusman, 2016, hlm. 229) Model Problem Based Learning merupakan inovasi dalam pembelajaran, karena kemampuan berpikir siswa betul-betul dioptimalisasikan melalui proses kerja kelompok atau tim yang sistematis, sehingga siswa dapat memberdayakan, mengasah, menguji, dan mengembangkan kemampuan berpikirnya secara berkesinambungan.

Model pembelajaran sangat berkaitan pula dengan hasil belajar peserta didik, dimana hasil belajar merupakan kemampuan-kemampuan yang dimilki siswa setelah menerima pengalaman belajarnya. (Sudjana, 2014, hlm. 15). Banyak faktor yang dapat mempengaruhi pada keberhasilan pelaksanaan pembelajaran diantaranya guru, orangtua, lingkungan dan lain sebagainya. Berdasarkan penelitian terdahulu yang diambil dari hasil penelitian yang dilakukan oleh Rina Yuniarti pada tahun 2014 dengan judul : "Penerapan Model Problem Based Learning untuk meningkatkan kreatifitas, rasa percaya diri dan hasil belajar siswa kelas IV SDN Cijerah 06 Pada Sub Tema Keberagaman Budaya Bangsaku" dapat meningkatkan kenaikan jumlah siswa yang melebihi batas KKM sebesar $90 \%$. Dalam hal ini, terlihat peningkatan yang signifikan baik dalam kreatifitas siswa, rasa percaya diri, serta hasil belajar yang sangat baik.

Selain itu hasil penelitian terdahulu yang diambil dari hasil penelitian yang dilakukan Nurul pada tahun 2014 dengan judul : "Model Problem Based Learning untuk meningkatkan sikap kerja sama dan hasil belajar siswa kelas IV SDN Cipamempeuk pada Sub tema Kebersamaan dalam Keberagaman" dapat mencapai hasil 95,4\% siswa mencapai KKM. Penelitian terdahulu yang dilakukan oleh Nurul tersebut membuktikan bahwa peningkatanpeningkatan terjadi saat proses pembelajaran menggunakan model problem based learning.

Keberhasilan penelitian tersebut memberikan gambaran yang positif mengenai model problem based learning dalam menunjang proses 
belajar mengajar namun kenyataan di lapangan masih banyak para guru yang belum menggunakan media dan model pembelajaran yang belum sesuai dengan pembelajaran. Penggunaan metode pembelajaran yang sering diterapkan selama ini adalah metode ceramah yaitu terlalu dominannya guru dalam proses pembelajaran sehingga aktivitas siswa dalam pembelajaran tergolong kurang terlihat dan mengakibatkan kurangnya pemahaman siswa dalam pembelajaran.

Untuk menciptakan suasana belajar yang dapat menarik, seorang guru harus mampu melakukan pengelolaan kelas yang baik dan membutuhkan suatu variasi model atau metode yang tepat dalam proses pembelajaran.

Kegiatan pembelajaran dapat dilakukan dengan berbagai model pembelajaran dan guru dapat memilih model pembelajaran yang sesuai dengan pelajaran yang akan dipelajari. Maka dari itu peneliti mencoba untuk mencari cara untuk meningkatkan aktivitas dan hasil belajar siswa baik dari segi afektif, kognitif maupun psikomotor agar tercipta pembelajaran yang sesuai dengan yang diharapkan.

\section{B. LANDASAN TEORI}

\section{Hakikat Pendidikan}

Pendidikan

dapat

mempengaruhi perkembangan manusia dalam seluruh aspek kepribadian dan kehidupannya. Pendidikan dapat mengembangkan berbagai potensi yang ada di dalam diri manusia. Dalam Undang-Undang Sistem Pendidikan Nasional No. 20 tahun 2003 pasal 3, menyatakan bahwa: Pendidikan adalah usaha sadar dan terencana untuk mewujudkan suasana belajar dan proses pembelajaran agar siswa secara aktif mengembangkan potensi dirinya untuk memiliki kekuatan spiritual keagamaan, pengendalian diri, kepribadian, kecerdasan, akhlak mulia, serta keterampilan yang diperlukan dirinya, masyarakat, bangsa dan negara.

G. Thompson 1957 (dalam Agus Taufik, dkk 2014, hlm. 1.3) menyatakan bahwa pendidikan adalah pengaruh lingkungan atas individu-individu untuk menghasilkan perubahan-perubahan yang tetap di dalam kebiasaan-kebiasaan, pemikiran, sikap-sikap, dan tingkah laku. Sedangkan menurut Hamalik Oemar ( 2015, hlm. 3 ) Pendidikan 
Pendas : Jurnal Ilmiah Pendidikan Dasar, ISSN Cetak : 2477-2143 ISSN Online : 2548-6950

adalah suatu proses dalam rangka mempengaruhi peserta didik supaya mampu menyesuaikan diri sebaik mungkin dengan lingkungan, dan dengan demikian akan menimbulkan perubahan dalam dirinya.

Dari beberapa pengertian di atas, peneliti menyimpulkan bahwa pendidikan merupakan usaha sadar manusia dengan dasar tujuan yang jelas dan dilakukan dalam rangka mengembangkan potensi yang dimiliki siswa melalui proses pembelajaran.

\section{Hakikat Pembelajaran}

Pembelajaran adalah proses interaksi siswa dengan pendidik dan sumber belajar pada suatu lingkungan belajar yang meliputi guru dan siswa yang saling bertukar informasi. Gagne (1977) menyatakan bahwa pembelajaran merupakan suatu proses modifikasi dalam kapasitas manusia yang bisa dipertahankan dan ditingkatkan levelnya. Woolfolk (1984, hlm. 159) menyatakan Pembelajaran merupakan perubahan sebagai hasil proses belajar ditunjukkan dalam berbagai bentuk. Wenger 1998 (dalam Miftahul Huda, 2013, hlm.2) mengatakan bahwa pembelajaran bukanlah aktivitas, seuatu yang dilakukan oleh seseorang ketika ia tidak melakukan aktivitas yang lain. Selain itu Sadiman 2006 (dalam Trianto Ibnu, 2014, hlm. 21) menyatakan bahwa pembelajaran adalah hasil guna yang diperoleh setelah pelaksanaan proses belajar mengajar.

Muhammad Surya 2011 (dalam Abdul Majid, 2015, hlm. 4) menyatakan bahwa pembelajaran adalah suatu proses yang dilakukan individu untuk memperoleh suatu perubahan perilaku yang baru secara keseluruhan, sebagai hasil dari pengalaman individu sendiri dalam interaksi dengan lingkungannya. Jadi, dapat disimpulkan bahwa pembelajaran adalah suatu proses interaksi peserta didik dengan pendidik dan sumber belajar pada suatu lingkungan belajar yang saling mempengaruhi proses pembelajaran sebagaimana dikemukakan oleh Gagne (1977) bahwa pembelajaran merupakan suatu proses modifikasi dalam kapasitas manusia yang bisa dipertahankan dan ditingkatkan levelnya.

\section{Hakikat Belajar}

Belajar pada hakikatnya adalah suatu proses yang ditandai dengan adanya pada diri seseorang, 
Pendas : Jurnal Ilmiah Pendidikan Dasar, ISSN Cetak : 2477-2143 ISSN Online : 2548-6950

perubahan sebagai hasil dari proses belajar dapat diindakasikan dalam berbagai bentuk seperti berubah pengetahuan, pemahaman, sikap, dan tingkah laku, kecakapan keterampilan, kemampuan, serta perubahan aspek-aspek yang lain yang ada pada individu yang belajar. Mudjiono 1999 (dalam Syaiful Sagala, 2010, hlm.17) memaparkan bahwa belajar merupakan tindakan dan perilaku siswa yang kompleks, sebagai tindakan belajar hanya dialami oleh siswa sendiri.

Menurut Reber 1986 (dalam Sofan Amri, 2013, hlm. 24) belajar merupakan proses memeperoleh pengetahuan dan sebagai perubahan kemampuan bereaksi yang relatif langgeng sebagai hasil latihan yang diperkuat. Menurut Burton 1984 (dalam Ahmad Susanto, 2013, hlm. 3) belajar dapat diartikan sebagai perubahan tingkah laku pada diri individu berkat adanya interaksi antara individu dengan individu lain dan individu dengan lingkungannya. Menurut Hamalik Oemar (2015, hlm. 36) Belajar adalah suatu proses, suatu kegiatan dan bukan suatu hasil dan tujuan. Belajar bukan hanya mengingat, akan tetapi lebih luas dari pada itu, yakni mengalami. Hasil belajar bukan suatu penguasaan hasil latihan, melainkan perubahan kelakuan.

Selain itu menurut Moh Suardi (2015, hlm. 9) bahwa belajar merupakan suatu proses dimana perilaku seseorang mengalami perubahan akibat pengalaman unsur. Selanjutnya pendapat lain mengenai belajar dikemukakan oleh Jufri (2017, hlm. 50) Belajar juga sering dimaknai sebagai adanya perolehan tingkah laku, pengetahuan, dan keterampilan baru yang terintegrasi dengan apa yang sudah dimiliki sebelumnya. Dari beberapa pengertian belajar di atas, dapat dipahami bahwa belajar adalah proses perubahan tingkah laku individu ke arah yang lebih baik yang bersifat relatif tetap akibat adanya interaksi dan latihan yang dialaminya untuk menciptakan perubahanperubahan dalam dirinya menuju kearah kesempurnaan hidup yang menyangkut unsur cipta, rasa dan karsa dalam ranah kognitif, afektif dan psikomotorik.

\section{METODE PENELITIAN}

Metode penelitian yang digunakan dalam penelitian ini adalah Penelitian Tindakan Kelas (PTK) yang memiliki peranan yang sangat 
penting dan strategis untuk meningkatkan mutu pembelajaran apabila diimplementasi dengan baik dan benar. Menurut Dave Ebbutt 1985 (dalam Iskandar Dadang, 2015, hlm.1) "penelitian tindakan kelas merupakan pembelajaran sistematis untuk meningkatkan praktik pendidikan dengan kelompok peneliti dimana tindakan dalam praktik dan refleksi mempengaruhi tindakan yang dilakukan."

Subjek penelitian ini adalah siswa siswi kelas IV SDN Nyomplong 1 Kecamatan Cipatat Kabupaten Bandung Barat tahun ajaran 20172018 yang berjumlah 20 orang yang terdiri dari 12 laki-laki dan 8 perempuan. Objek penelitian ini adalah meningkatan aktivitas belajar siswa kelas IV SDN Nyomplong 1 Kecamatan Cipatat Kabupaten Bandung Barat tahun 2017-2018 melalui model pembelajaran problem based learning pada subtema Keberagaman Budaya Bangsaku. Penelitian ini dilaksanakan pada pertengahan bulan juli 2017, penelitian akan dilaksanakan semester 1 pada subtema keberagaman budaya bangsaku dan kurikulum yang digunakan adalah Kurikulum 2013 (Kurtilas).

\section{HASIL PENELITIAN}

Berdasarkan hasil penelitian yang telah dilaksanakan pada siklus I, II, dan III dalam proses pembelajaran. Pembahasan ini bertujuan untuk menjawab permasalahan yang ada dalam penelitian. Hal ini untuk mengetahui pelaksanaan pembelajaran dengan menggunakan model pembelajaran problem based learning yang merupakan salah satu upaya untuk meningkatkan aktivitas belajar siswa kelas IV SDN Nyomplong 1. Adapun yang dibahas sebagai berikut:

\section{Rencana}

Pelaksanaan

\section{Pembelajaran (RPP)}

Rencana

pelaksanaan pembelajaran (RPP) dapat meningkatkan hasil belajar pada subtema keberagaman budaya bangsaku dengan data yang telah dikumpulkan melalui rubrik penilain RPP yang dinilai oleh observer (wali kelas IV). Hal ini dilakukan untuk mengukur kualitas RPP dari setiap komponennya. Pada siklus I memperoleh nilai $74 \%$ dengan kategori baik, karena pada siklus I masih terdapat beberapa aspek yang kurang memenuhi kriteria seperti kurangnya perumusan dan 
Pendas : Jurnal Ilmiah Pendidikan Dasar, ISSN Cetak : 2477-2143 ISSN Online : 2548-6950

penggorganisasian materi, media yang digunakan pun masih kurang dengan skenario yang peneliti susun, maka dari itu observer memberikan saran kepada peneliti agar memperbaiki dan mengembangkan lagi RPP untuk siklus selanjutnya.

Pada siklus II rencana pelaksanaan pembelajaran (RPP) mengalami peningkatan pada kekurangan di siklus I, namun masih ada aspek yang yang belum signifikan perbaikannya oleh peneliti seperti perumusan dan penggorganisasian materi, dan penilaian hasil belajar. Pada siklus II ini peneliti memperoleh nilai sebesar $85 \%$ dalam kategori sangat baik. Pada siklus III rencana pelaksanaan pembelajaran (RPP) mengalami peningkatan yang signifikan terutama pada kekurangan di siklus I dan II perumusan dan penggorganisasian materi sudah diperbaiki oleh peneliti. Pada siklus III ini peneliti memperoleh nilai sebesar 3.78 dengan presentase 95\% dalam kategori sangat baik.

Kegiatan yang dilakukan mulai dari perencanaan pembelajaran hingga pelaksanaan pembelajaran, perencanaan dilakukan untuk menyusun rencana pelaksanaan pembelajaran dalam implementasi model pembelajaran problem based learning. Hal ini berkaitan dengan apa yang dikatakan Zuhdan, dkk (2011, HIm.16) yang menyatakan bahwa "Perangkat pembelajaran adalah alat atau perlengkapan untuk melaksanakan proses yang memungkinkan pendidik dan siswa melakukan kegiatan pembelajaran". Dengan demikian dari teori tersebut sesuai dengan indikator yang hendak ingin dicapai khususnya dalam rencana pelaksanaan pembelajaran (RPP). Dalam kegiatan RPP dapat dikatakan berhasil, karena pada setiap siklus nilai yang diperoleh peneliti mengalami peningkatan. Data peningkatan rencana pelaksanaan pembelajaran (RPP) pada siklus I, II dan III yang peneliti susun dengan menggunakan model pembelajaran problem based learning di kelas IV SDN Nyomplong 1 dapat dilihat pada tabel 1 di bawah ini:

\section{Tabel 1 Peningkatan Penilain RPP}

\begin{tabular}{|c|c|c|}
\hline Siklus & Presentase & Kategori \\
\hline Siklus I & $74 \%$ & Baik \\
\hline Siklus II & $85 \%$ & $\begin{array}{c}\text { Sangat } \\
\text { Baik }\end{array}$ \\
\hline Siklus III & $95 \%$ & $\begin{array}{c}\text { Sangat } \\
\text { Baik }\end{array}$ \\
\hline
\end{tabular}

Berdasarkan hasil rencana pelaksanaan pembelajaran (RPP) di atas dapat disimpulkan bahwa penggunaan model pembelajaran 
Pendas : Jurnal Ilmiah Pendidikan Dasar, ISSN Cetak : 2477-2143 ISSN Online : 2548-6950

Volume II Nomor 1, Juni 2017

problem based learning dapat meningkatkan aktivitas belajar siswa pada subtema keberagaman budaya bangsaku di SDN Nyomplong 1.

\section{a. Pelaksanaan Aktivitas Pendidik}

Penilain aktivitas pendidik (peneliti) oleh observer mengalami peningkatan pada setiap siklusnya. Pada siklus I memperoleh nillai $74 \%$ dengan kategori baik adapun alasan obeserver pada siklus I yaitu materi pembelajaran masih belum sesuai dengan indikator, strategi pembelajaran yang mendidik, penggunaan bahasa yang benar dan tepat. Namun pada tindakan siklus II peneliti mendapatkan nilai $88 \%$ dengan kategori sangat baik, karena menurut observer pendidik sudah berusaha untuk memperbaiki kekurangan yang ada pada siklus I. Pada tindakan siklus III peneliti mendapatkan nilai $96 \%$ dengan kategori sangat baik karena menurut observer pada siklus III ini pendidik menunjukan kinerja yang sudah sempurna dan optimal terlihat ada beberapa tahapan yang hampir semua terlaksana oleh peneliti terutama pada kegiatan inti pembelajaran meningkat dari siklus sebelumnya.
Kegiatan yang dilakukan dalam pelaksanaan pembelajaran dalam implementasi model pembelajaran problem based learning. Hal ini berkaitan dengan apa yang dikatakan Agung Suprijono (2016, hlm. 202) yang menyatakan bahwa "Problem Based Learning menggunakan masalah nyata (kontekstual) supaya peserta didik belajar tentang cara berpikir kritis, keterampilan memecahkan masalah dan memperoleh pengetahuan".Data peningkatan pelaksanaan pembelajaran pada siklus I. II dan III yang peneliti susun dengan menggunakan model pembelajaran problem based learning pada subtema keberagaman budaya bangsaku di kelas IV SDN Nyomplong 1 dapat dilihat pada tabel 2 dibawah ini:

Tabel 2 Peningkatan Penilaian

Pelaksanaan Pembelajaran

\begin{tabular}{|c|c|c|}
\hline Siklus & $\begin{array}{c}\text { Presentase } \\
\%\end{array}$ & Kategori \\
\hline Siklus I & $74 \%$ & Baik \\
\hline Siklus II & $88 \%$ & $\begin{array}{c}\text { Sangat } \\
\text { baik }\end{array}$ \\
\hline Siklus III & $96 \%$ & $\begin{array}{c}\text { Sangat } \\
\text { baik }\end{array}$ \\
\hline
\end{tabular}

Berdasarkan hasil pelaksanaan pembelajaran di atas dapat disimpulkan bahwa proses pelaksanaan pembelajaran dengan penggunaan model pembelajaran 
Pendas : Jurnal Ilmiah Pendidikan Dasar, ISSN Cetak : 2477-2143 ISSN Online : 2548-6950

Volume II Nomor 1, Juni 2017

problem based learning dapat meningkatkan aktivitas belajar siswa pada subtema keberagaman budaya bangsaku di kelas IV SDN Nyomplong 1.

\section{b. Penilaian Aktivitas Siswa}

Penilain aktivitas siswa mengalami peningkatan pada setiap siklusnya. Padas iklus I memperoleh nila\%i 66,2 dengan kategori baik. Namun pada tindakan siklus II peneliti mendapatkan nilai $75 \%$ dengan kategori sangat baik, lalu pada tindakan siklus III peneliti mendapatkan nilai $93,5 \%$ dengan kategori sangat baik. Kegiatan yang dilakukan dalam pelaksanaan pembelajaran dalam meningkatkan aktivitas siswa sangatlah penting. Karena aktivitas merupakan salah satu faktor utama dalam keberhasilan suatau pembelajaran. Seperti yang dikemukakan oleh Apriliawati 2011 (dalam Mufidah, dkk., 2013, hlm. 118) menyatakan bahwa "Aktivitas belajar adalah kegiatan yang dilakukan siswa selama proses pembelajaran. Aktifitas tersebut mencerminkan keinginan siswa untuk belajar".

Data peningkatan pelaksanaan aktivitas siswa pada siklus I. II dan III yang peneliti susun dengan menggunakan model pembelajaran problem based learning pada subtema keberagaman budaya bangsaku di kelas IV SDN Nyomplong 1 dapat dilihat pada tabel 3 di bawah ini:

Tabel 3 Peningkatan Hasil Pelaksanaan Pembelajaran Aktivitas Siswa

\begin{tabular}{|c|c|c|}
\hline Siklus & $\begin{array}{c}\text { Presentase } \\
\%\end{array}$ & Kategori \\
\hline Siklus I & $66,2 \%$ & Baik \\
\hline Siklus II & $75,0 \%$ & Baik \\
\hline Siklus III & $93,5 \%$ & $\begin{array}{c}\text { Sangat } \\
\text { baik }\end{array}$ \\
\hline
\end{tabular}

\section{Hasil Belajar Siswa}

Hasil belajar yang diperoleh peserta didik dari tiga ranah yaitu kognitif, afektif, dan psikomotor sehingga bisa mencapai tujuan pembelajaran yang diharapkan yaitu melalui belajar yang dapat terjadi perubahan (peningkatan) bukan hanya pada aspek kognitif, tetapi juga pada aspek lainnya. Hal ini sesuai dengan yang diungkapkan oleh Bloom dalam Nana Sudjana (2010, hal. 23) hasil belajar dalam rangka studi yang dicapai melalui tiga katagori ranah yaitu ranah kognitif, afektif, psikomotor, yakni:

\section{a. Hasil Belajar Siswa Ranah Afektif}

Dalam penilaian afektif terdapat 2 sikap yang diteliti yaitu sikap peduli 
Pendas : Jurnal Ilmiah Pendidikan Dasar, ISSN Cetak : 2477-2143 ISSN Online : 2548-6950

Volume II Nomor 1, Juni 2017

dan santun. Dari kedua sikap tersebut terdapat peningkatan yang dapat dilihat dari persentase. Dimulai dari sikap yang pertama akan dibahas yaitu sikap peduli. Hasil dari sikap peduli ini dibagi menjadi 3 siklus, berdasarkan hasil di siklus I terdapat nilai dengan presentase $61 \%$, pada siklus II terdapat nilai dengan presentase 79\%, dan pada siklus III dengan presentase 90\%. Pada sikap kedua yaitu sikap santun. Pada siklus I terdapat nilai dengan presentase $60 \%$, pada siklus II terdapat nilai dengan presentase $81 \%$, dan pada siklus III sebesar $92 \%$.

Tabel 4 Peningkatan Hasil Belajar Siswa Ranah Afektif

\begin{tabular}{|c|c|c|c|}
\hline \multirow{2}{*}{ Siklus } & \multicolumn{2}{|c|}{ Presentase } & \multirow{2}{*}{ Kategori } \\
\cline { 2 - 3 } & Peduli & Santun & \\
\hline I & $61 \%$ & $60 \%$ & Cukup \\
\hline II & $79 \%$ & $81 \%$ & Baik \\
\hline III & $90 \%$ & $92 \%$ & $\begin{array}{c}\text { Sangat } \\
\text { Baik }\end{array}$ \\
\hline
\end{tabular}

b. Hasil Belajar Siswa Ranah Kognitif

Berdasarkan Observasi hasil belajar siswa ranag kognitif mengalami peningkatan pada setiap siklusnya. Padas siklus I memperoleh nilai presentase $45 \%$, pada tindakan siklus II peneliti mendapatkan nilai presentase $60 \%$, lalu pada tindakan siklus III peneliti mendapatkan nilai presentase 85\%. Untuk lebih jelasnya dapat dilihat pada tabel 5 dibawah ini: Tabel 5 Hasil Belajar Siswa Ranah Kognitif

\begin{tabular}{|c|c|c|}
\hline Siklus & Presentase & Kategori \\
\hline I & $45 \%$ & Cukup \\
\hline II & $60 \%$ & Cukup \\
\hline III & $85 \%$ & Baik \\
\hline
\end{tabular}

c. Hasil Belajar Siswa Ranah

\section{Psikomotor}

Berdasarkan Observasi hasil belajar siswa ranah psikomotor mengalami peningkatan pada setiap siklusnya. Padas iklus I memperoleh nilai dengan presentase $58 \%$, pada tindakan siklus II peneliti mendapatkan nilai dengan presentase $81 \%$ lalu pada tindakan siklus III peneliti mendapatkan nilai dengan presentase $91 \%$. Untuk lebih jelasnya dapat dilihat pada tabel 6 dibawah ini:

Tabel 6 Hasil Belajar Siswa Ranah

\section{Psikomotor}

\begin{tabular}{|c|c|c|}
\hline Siklus & Presentase & Kategori \\
\hline I & $58 \%$ & Cukup \\
\hline II & $81 \%$ & Baik \\
\hline III & $91 \%$ & Sangat Baik \\
\hline
\end{tabular}

Hasil belajar ranah psikomotor pada siklus I,II,III dapat dijelaskan bahwa dalam siklus I sebesar 58\%, Siklus II sebesar 81\%, Siklus III 
Pendas : Jurnal Ilmiah Pendidikan Dasar, ISSN Cetak : 2477-2143 ISSN Online : 2548-6950 Volume II Nomor 1, Juni 2017

sebesar $91 \%$ dengan rata-rata sebesar 76,5 dan dikategorikan Baik.

\section{E. KESIMPULAN}

Berdasarkan hasil penelitian dengan judul "Penggunaan Model Problem Based Learning Untuk Meningkatkan Aktivitas Belajar Siswa Pada Subtema Keberagaman Budaya Bangsaku". Penelitian tindakan kelas ini dilakukan di kelas IV SDN Nyomplong 1.

Perencanaan pelaksanaan pembelajaran dengan menggunakan model pembelajaran problem based learning pada subtema keberagaman budaya bangsaku dapat meningkatkan aktivitas belajar siswa kelas IV SDN Nyomplong 1 terlihat adanya peningkatan. Rencana pelaksanaan pembelajaran yang peneliti buat sudah terlaksana dengan baik, hal tersebut dapat dilihat dari hasil penilaian observasi yang diberikan observer mengalami peningkatan setiap siklusnya. Pada siklus I mendapatkan nilai 2.95 dengan kategori baik., pada siklus II mendapatkan nilai 3.40 dengan kategori sangat baik, dan pada siklus III mendapatkan nilai 3.78 dengan kategori sangat baik.
Pelaksanaan

pembelajaran dengan menggunakan model pembelajaran problem based learning pada subtema keberagaman budaya bangsaku untuk meningkatkan aktivitas belajar siswa kelas IV SDN Nyomplong 1 terlihat adanya peningkatan dalam pembelajaran. pelaksanaan pembelajaran yang peneliti lakukan sesuai dengan langkah-langkah pembelajaran problem based learning yaitu diawali dengan pemberian rangsangan atau situmulus, merumuskan masalah, mengajukan hipotesis, mengumpulkan data, menguji hipotesis dan terakhir menarik kesimpulan. Pelaksanaan pembelajaran Pada siklus I diperoleh nilai 3.00 dengan kategori baik, pada siklus II diperoleh nilai 3.52 dengan kategori sangat baik, dan pada siklus III diperoleh nilai 3.84 dengan kategori sangat baik.

Peningkatan aktivitas belajar siswa dengan menggunakan model pembelajaran problem based learning pada subtema keberagaman budaya bangsaku kelas IV SDN Nyomplong 1 mengalami peningkatan. Aktivitas belajar pada siklus I diperoleh nilai dengan kategori baik, pada siklus II diperoleh nilai dengan kategori baik, 
Pendas : Jurnal Ilmiah Pendidikan Dasar,

dan pada siklus III diperoleh nilai dengan kategori sangat baik yang dinyatakan tuntas.

Peningkatan sikap peduli dan santun (ranah afektif) dengan model pembelajaran problem based learning pada subtema keberagaman budaya bangsaku kelas IV SDN Nyomplong 1 mengalami peningkatan. Dalam sikap peduli, di siklus I diperoleh nilai dengan kategori cukup, pada siklus II diperoleh nilai dengan kategori baik dan pada siklus III diperoleh nilai dengan kategori sangat baik. Sedangkan dalam sikap santun siklus I diperoleh nilai dengan kategori cukup, pada siklus II diperoleh nilai dengan kategori bsik, dan pada siklus III diperoleh nilai dengan kategori sangat baik. Dengan ini sikap peduli dan santun dalam setiap siklus selalu mengalami peningkatan.

Peningkatan dalam mencari informasi (ranah informasi) peserta didik dengan menggunakan model pembelajaran problem based learning pada subtema keberagaman budaya bangsaku kelas IV SDN Nyomplong 1 mengalami peningkatan. Pada siklus I diperoleh nilai dengan kategori cukup, pada siklus II diperoleh nilai dengan kategori cukup, dan pada siklus III diperoleh nilai dengan kategori baik.

Peningkatan hasil belajar siswa (ranah kognitif) dengan menggunakan model pembelajaran problem based learning pada subtema keberagaman budaya bangsaku kelas IV SDN Nyomplong 1 mengalami peningkatan. Hasil belajar pada siklus I dari 20 peserta didik diperoleh nilai peserta didik yang dinyatakan tuntas sebanyak 9 peserta didik, pada siklus II diperoleh nilai peserta didik yang dinyatakan tuntas sebanyak 12 peserta didik, dan pada siklus III diperoleh nilai yang dinyatakan tuntas sebanyak 17 peserta didik. Maka dalam hasil belajar peserta didik selalu mengalami peningkatan tiap siklusnya.

Hasil belajar secara keseluruhan mulai dari ranah afektif, kognitif maupun psikomotor selalu mengalami peningkatan yang baik dalam setiap siklusnya, dan jika di kalkulasikan dengan berbagai ranah baik afektif, kognitif maupun psikomotor maka terdapat hasil belajar keseluruhan sebesar 89 dengan kategori Sangat baik.

Dari uraian diatas, hasil dari aktivitas belajar meningkat setiap 
Pendas : Jurnal Ilmiah Pendidikan Dasar, ISSN Cetak : 2477-2143 ISSN Online : 2548-6950

Volume II Nomor 1, Juni 2017

siklusnya. Selain itu terdapat hasil belajar peserta didik yang meningkat setiap siklusnya. Hasil belajar tersebut diperoleh dari tiga ranah yaitu ranah kognitif, ranah efektif dan ranah psikomotor. Pada ranah afektif peniliti hanya memfokuskan pada asfek sikap peduli dan santun, karena aspek sikap peduli dan santun merupakan sikap dorongan untuk lebih mengenal kelebihan dan kekurangan diri sendiri, dan ranah psikomotor pada keterampilan peserta didik dalam mencari informasi.

\section{DAFTAR PUSTAKA}

Akhmad, Imran. (2016). Sumber belajar dan Teknologi Komunikasi dan Informasi untuk Pengembangan Berkelanjutan. Keprofesian CV.Setiaji

Amir, Taufiq. (2009). Inovasi Pendidikan Melalui Problem Based Learning. Jakarta: Prenadamedia Group.

Amri, Sofan. (2013). Pengembangan \& Model Pembelajaran dalam Kurikulum 2013. Jakarta: PT.Prestasi Pustakaraya.

Anggraeni, Mia. (2016). Penggunaan Model Discovery Learning Untuk Meningkatkan Aktivitas dan Hasil Belajar dalam Pembelajaran IPA Materi Fungsi Organ Tubuh Manusia Dan Hewan (Penelitian Tindakan Kelas pada Siswa Kelas V SDN Nambo Jl. Raya Haurgeulis-Gantar KM 06 Kecamatan Gantar Kabupaten

$\begin{array}{ll}\text { Indramayu } & \text { Tahun } \begin{array}{c}\text { Pelajaran } \\ \text { 2016-2017). }\end{array} \\ \text { Universitas } & \text { Pandung: } \\ \text { diterbitkan. } & \end{array}$

Aunurrahman. (2014). Belajar dan Pembelajaran. Bandung: Alfabeta

Cahyo, N. Agus. (2013). Panduan aplikasi teori-teori belajar mengajar. Jogjakarta: DIVA press

Departemen Pendidikan Nasional. (2003). Undang-Undang Nomor 20 Tahun 2003 Tentang Sistem Pendidikan Nasional. Jakarta: Depdiknas.

Departemen Pendidikan Nasional. (2005). Undang-Undang Nomor 14 Tahun 2005 Tentang Guru dan Dosen. Jakarta: Depdiknas.

Dimyati, Mudjiono. (2006). Belajar dan Pembelajaran. Jakarta: PT Rineka Cipta.

Endah, Loeloek. (2013). Panduan Memahami Kurikulum 2013. Jakarta: PT. Prestasi Pustakaraya.

Habibah, Desi. (2015). Penerapan Model Discovery Learning Untuk Meningkatkan Aktivitas dan Prestasi Belajar Siswa Dalam Mutu Pengajaran IPA Pada Materi Fungsi Organ Tubuh Manusia dan Hewan. Bandung: Universitas Pasundan, tidak diterbitkan

Hajar, Ibnu. (2013). Panduan Lengkap Kurikulum Tematik. Yogyakarta: DIVA Press.

Hamalik, Oemar. (2015). Kurikulum dan Pembelajaran. Jakarta: Bumi Aksara.

Hosnan. (2014). Pendekatan Saintifik dan Kontekstual dalam pembelajaran Abad 21. Bogor: Ghalia Indonesia http://jurnal.arraniry.ac.id/index.php/didaktika/ar 
Pendas : Jurnal Ilmiah Pendidikan Dasar, ISSN Cetak : 2477-2143 ISSN Online : 2548-6950

ticle/viewFile/497/415 (Dikutip dan diakses pada tanggal 09 Mei 2017).

Huda, Miftahul. (2013). Model-Model Pengajaran dan Pembelajaran. Yogyakarta: Pustaka Pelajar Offset.

Ibnu, Trianto. (2014). Mendesain Model Pembelajaran Inovatif, Progresif, dan Konstektual. Jakarta: PRENADAMEDIA GROUP.

Iskandar, Dadang dan Narsim. (2015). Penelitian Tindakan Kelas dan Publikasinya untuk Kenaikan Pangkat dan Golongan Guru \& Pedoman Penulisan PTK bagi Mahasiswa. Cilacap: Ihya Media.

Jihad, Asep. Haris, Abdul. (2013). Evaluasi Pembelajaran. Yogyakarta: Multi Pressindo.

Jufri, Wahab. 2017. Belajar Dan Pembelajaran Sains. Bandung: Pustaka Reka Cipta.

Komalasari, Kokom. (2013). Pembelajaran Kontekstual Konsep dan Aplikasi. Bandung: Refika Aditama.

Kustawan, Dedy. (2013). Analisis Hasil Belajar, Program Perbaikan dan Pengayaan Peserta Didik Berkebutuhan Khusus. Jakarta Timur: Luxima Metro Media.

Kwan, I. (2009). The Routledge International Handbook of Higher Education. New York: Taylor \& Francis.

Majid, Abdul. (2013). Perencanaan Pembelajaran. Bandung: Remaja Rosdakarya.

Majid, Abdul. (2014). Pembelajaran Tematik Terpadu. Bandung: Remaja Rosdakarya Offset.
Majid, Abdul. (2015). Strategi Pembelajaran. Bandung: Remaja Rosdakarya Offset.

Mufida, Umrothul dan Najlathun Naqiyah. (2013). Penerapan Strategi Pemodelan Kognitif Untuk Menciptakan Rasa Percaya Dirisiswa bertanya Kepada Guru di SMAN 1 Krembung-Sidoarjo. JURNAL BK UNESA. Volume 04 Nomor 01 Tahun 2013, halaman 243-250. (Di akses tanggal 28 April 2017).

Nurlatifah, Desi Habibah. (2015). Penerapan Model Discovery Leraning Untuk Meningkatkan Aktivitas dan Prestasi Belajar Siswa Dalam Mata Pelajaran IPA Pada Materi Fungsi Organ Tubuh Manusia dan Hewan : Tidak diterbitkan.

Rusman, (2016). Model-model Pembelajaran:Mengembangkan Profesionalisme. Jakarta: Rajawali Pers.

Sagala. Syaiful. (2010). Konsep dan Makna Pembelajaran. Bandung : Alfabeta.

Sardiman. (2016). Interaksi Dan Motivasi Belajar Mengajar. Jakarta: Rajawali Pers.

Sa'ud. Syaefuddin. (2006). Pembelajaran Terpadu. Bandung: UPI Press.

Satori, Djam'an. (2011). Profesi Keguruan. Jakarta: Universitas Terbuka

Suardi, Moh. (2015). Belajar \& Pembelajaran. Yogyakarta: Deepublish.

Sudjana, Nana \& Ibrahim (2004). Penelitian dan Penilaian Pendidikan. Bandung: Sinar Baru Algesindo. 
Pendas : Jurnal Ilmiah Pendidikan Dasar, ISSN Cetak : 2477-2143 ISSN Online : 2548-6950

Volume II Nomor 1, Juni 2017

Sugiyono. (2013). Metode Penelitian Pendidikan

(Pendekatan

Kuantitatif, Kualitatif, dan R\&D). Bandung: Alfabeta

Suprijono, Agung. (2016). ModelModel Pembelajaran Emansipatoris. Yogyakarta: Pustaka Pelajar.

Surya, Muhamad. (2013). Psikologi Guru. Bandung: Alfabeta

Susanto, Ahmad. (2013). Teori Belajar \& Pembelajaran di Sekolah Dasar. Jakarta: Prenadamedia Group.

Suteja, Reza. (2016). Penggunaan Model Cooperative Learning Tipe Jigsaw untuk Meningkatkan Sikap Semangat Kebangsaan dan Hasil Belajar Siswa pada Mata Pelajaran IPS Materi Persiapan Kemerdekaan Indonesia. Bandung: Universitas Pasundan, Tidak Diterbitkan.

Paizaluddin dan Ermalinda. (2016). Penelitian Tindakan Kelas
(Classroom Action Research) Panduan Teoritis dan Praktis. (2016). Bandung: Alfabeta.

Taufik, Agus, dkk. (2014). Pendidikan Anak di SD. Jakarta: Universitas Terbuka Trianto. (2014). Mendesain Model Pembelajaran Inovatif, Progesif, dan Kontekstual. Jakarta: Prenadamedia.

Yusuf, Muh. (2009). Pengaruh Cara Dan Motivasi Belajar Terhadap Hasil Belajar Programmable Logic Controller (PLC) Siswa Kelas III Jurusan Listrik SMK NEGERI 5 MAKASSAR. 1(2), 34. Retrieved fromhttp://www.ftunm.net/medtek/Jurnal\%20Medte k\%20Vo.\%201 No.2 Oktober\%2 02009/M.\%20Yusuf\%20Mappeas se.pdf

( Di akses tanggal 4 Mei 2017).

Zuhdan. (2014). Belajar dan Pembelajaran. Bandung: Alfabeta. 